\title{
Review: Sheila Skaff, Studying Ida
}

\section{Lucia Szemetova}

https://doi.org/10.15664/fcj.v0i17.2060

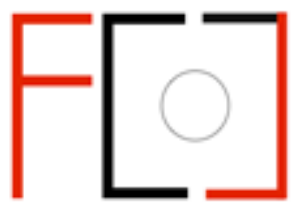

Frames Cinema Journal

ISSN 2053-8812

Issue 17 (Jun 2020)

(c) (i)

http://www.framescinemajournal.com 


\section{Studying Ida}

By Sheila Skaff

\section{Auteur Publishing, 2018}

Reviewed by Lucia Szemetova, University of St Andrews

Pawel Pawlikowski's Ida (2013), one of the most important European films of the last decade, has received as much praise as criticism. On its release in 2014, the film was celebrated for its captivating black-and-white cinematography, daring storyline, and outstanding acting performances. The film's plot about a nun novice who discovers that she is of Jewish origins, however, also sparked a great deal of controversy around Polish history and memory. Amidst these often divided receptions, Sheila Skaff in her book Studying Ida defines the film as a meditation. The book's central argument revolves around the film's "muted reflections" (9) on tragedy, its ability to come to terms with pain in silence. Skaff, a New York-based professor of Film Studies and a published writer on Polish cinema, brings a level of expertise to not only the close analysis of the film itself but its wider historical and socio-political context.

The historical backdrop of Ida is emphasised throughout the book, with Skaff setting out a clear historical and political framework in which the film should be assessed. Although the director has repeatedly stressed that $I d a$ is not a Holocaust film, it absorbs the atrocities of World War II and reflects on their impact in 1960s Poland. The film discusses pogroms during Nazi occupation and their consequences, examines tensions between Catholic and Jewish populations, and comments on the power structures in Communist Poland. Skaff engages at length with Jan Tomasz Gross' ground-breaking academic text that first revealed the brutal murder of Jewish citizens by their Polish neighbours in Jedwabne, a fundamental context of the film (Chapter 4). ${ }^{1}$ She not only traces real-life events influencing the film's plot and characters, such as a Catholic priest discovering his Jewish origins or Communist show trials, but lists other recent documentary and fiction films that reflect on the dark spots of Polish history (Chapter 6). ${ }^{2}$ Skaff argues that through these obvious historical references the film delves into the complexities of Polish identity. She identifies three main concepts - emigration, lustration, and restitution - pivotal to Polish national consciousness, all of which the film touches upon. Thus, she brings to attention how the contested past is approached, represented, and institutionalised in contemporary Poland and how it affects memory and identity politics. Recognising this context, according to her, explains $I d a^{\prime}$ s complexity as well as its polarised reception.

Skaff's discussion combines a mix of past and present Polish context with a study of Ida's cinematic merits. It follows the film chronologically with a detailed scene-to-scene analysis while outlining the major motifs in the mise-en-scène (Chapter 1), narrative and genre conventions (Chapter 2), character representation (Chapter 2), and use of music (Chapter 3). With great attention to detail, she examines how the film's strategies of framing, editing, and lighting come together in such a unique cinematic look of "filmic poetry" (44). Building on the central argument, Skaff claims that slow editing, single-source lighting, and vertical framing force the viewer to contemplate, specifically on the recent past. According to Skaff, this character-driven road movie presents the country like a cemetery, where the black-and-white images, endued with nostalgia, resemble personal photographs and memories of post-war Poland. In addition, the soundtrack, or more precisely the absence of it, offers a retrospective journey to the Polish jazz scene as well as highlighting the significance of silence in Ida. Besides the film's meditative qualities, the book traces Pawlikowski's career and personal life and the myriads of inspirations that came together in the 
making of Ida. From visual arts to music, Skaff mentions the influence of Tadeusz Rolke's reportage photography (Chapter 1), the post-war poems on trauma by Tadeusz Rozewicz and Maya Deren (Chapter 2), Polish jazz (Chapter 3), and even the characters' real-life counterparts (Chapters 2 and 3).

In the concluding chapter (Chapter 7), Skaff steps beyond the film text and considers the afterlife of Ida. This part presents an extensive list of festival attendances and awards the film has received while also balancing the highly positive Western reviews with the divided domestic receptions. For the latter, she includes responses from Catholic communities, online film magazines, and public intellectuals, to give an overview of the diverse discourse caused by the film. Besides its obviously controversial topic, Ida has been condemned for reinforcing anti-Semitic stereotypes and false representation of life in the convent. The author draws attention to heated ideological interpretations, which are telling, more often with regard to the current political context than the film's approach to the past. As a specific example, Skaff brings up the Polish national television (TVP) scandal in 2016, when Ida was altered and manipulated during screening to stress its historical inaccuracy. The 44 members of the Guild of Polish directors, including Pawlikowski himself, wrote an open letter of outrage.

Taken as a whole, the book is a short yet concise attempt to analyse this highly disputed film, suitable for both experts and curious cinephiles. Skaff uses simple language and follows a clear structure, which results in a useful guide for the film. The descriptions are always paired with the relevant historical and political issues, both of the past and the present moment. By identifying the film's key themes and visual strategies she manages to highlight its multi-layered meanings and balance it with its potentials for controversy. However, the book falls short on the matter of the meditation argument, as it never explores why coming to terms with trauma and loss has to happen in silence in the first place. Similarly, the major historical events clarifying the context of the film are listed as self-explanatory when the wider issues at stake in contemporary Poland are overlooked. Ending on a heavy note with the TVP scandal, the author only hints at the extent of the national institutions' control over national narratives. Significantly, the book came out in the same year as an amendment was passed to the Polish Memory Law which criminalises the attribution of responsibility for Nazi crimes to the Polish state or nation - a crucial step in current political climate, yet one that is only mentioned in passing. Moreover, though the book anchors the film in the Polish context it does not comment on the role of visual media in this process more widely. Throughout Skaff relies overwhelmingly on film reviews, reports, and interviews, whose accuracy and significance are never questioned. She fails to connect the film to rich scholarly work on representations of history, memory, and identity politics. Ida's contribution to film history or its place beyond the Polish context never gets considered.

In many ways, Studying Ida is a simultaneously simple and comprehensive monograph one that successfully clarifies and provides further insight into a film that argues for calmness yet caused such unrest. Its length, comprehensibility, and accuracy make it a suitable read for those seeking structure as well as a summary of Poland's complex twentieth century. It certainly serves as a useful starting point and an insightful teaching aid for understanding $I d a$, a film that continues to spark critical discussions.

\footnotetext{
${ }^{1}$ Jan Tomasz Gross, Neighbors: The Destruction of the Jewish Community in Jedwabne, Poland (Penguin, 2002).
} 
2 The book mentions the play Our Class (Tadeusz Słobodzianek, 2008), the documentary films Birthplace (Pawel Loziński, 1992) and Where is My Older Brother Cain? (Agnieszka Arnold, 1999), and the film Aftermath (Władysław Pasikowski, 2012). 